This is an electronic reprint of the original article. This reprint may differ from the original in pagination and typographic detail.

Author(s): Vos, Marita; Schoemaker, Henny; Luoma-aho, Vilma

Title: $\quad$ Setting the agenda for research on issue arenas

Year: $\quad 2014$

Version:

Please cite the original version:

Vos, M., Schoemaker, H., \& Luoma-aho, V. (2014). Setting the agenda for research on issue arenas. Corporate Communications, 19(2), 200-215.

https://doi.org/10.1108/CCIJ-08-2012-0055

All material supplied via JYX is protected by copyright and other intellectual property rights, and duplication or sale of all or part of any of the repository collections is not permitted, except that material may be duplicated by you for your research use or educational purposes in electronic or print form. You must obtain permission for any other use. Electronic or print copies may not be offered, whether for sale or otherwise to anyone who is not an authorised user. 


\title{
Setting the agenda for research on issue arenas
}

\author{
Marita Vos, Henny Schoemaker, and Vilma Luoma
}

\begin{abstract}
Purpose -This paper seeks to contribute to the field of corporate communication by clarifying the theoretical basis of communication in issue arenas and proposing an agenda for research on issue arenas.
\end{abstract}

Design/Methodology/Approach - Drawing on insights from stakeholder thinking, network theory, issues management, and agenda-setting theory, the authors identify different levels of analysis that could explain the behaviour of organizations in the public debate on current issues.

Findings - The organization-centred approach is replaced by a strong emphasis on interaction in networks of organizations, groups and individuals. Decision-making on communication strategies can be further developed by analysing the particularities of each issue arena, in particular the characteristics of the issue and the actors involved as well as the course of the debate and the communication strategies utilized in stakeholder interaction.

Research limitations/implications - This purely theoretical approach calls for further research, but offers an agenda and suggests four starting levels for analysis.

Practical implications - This paper provides a timely approach to the analysis of corporate communication that may help understand the complexities of a rapidly changing organizational environment and, ultimately, assist organizations in developing customized communication strategies suited to each issue arena relevant to their operations.

Social implications - The analysis of communication strategies in issue arenas may also add insight into collaboration and problem solving in issue arenas.

Originality/value - Insights from various theories are brought together to serve as a starting point for the further analysis of communication in issue arenas.

Keywords - Issue arena, public debate, issues management.

Paper type - Conceptual paper 
Marita Vos, Henny Schoemaker, and Vilma Luoma, Setting the agenda for research on issue arenas. Corporate Communications, an International Journal, Vol.18 No. 2, pp. 200-2015.

\section{Introduction}

There is a growing need to understand where communication should take place in the era of the new and social media (Castells, 2009). Corporations are embracing new tools and services online, yet analysis of these new possibilities continues to be lacking. This paper seeks to clarify the theoretical basis of the concept of the issue arena and propose a research agenda for research on issue arenas. The concept of the issue arena has previously been introduced into this field (Luoma-aho and Vos, 2009 and 2010). By further refining the concept and clarifying its theoretical basis, different levels of analysis for issue arena research can be demonstrated. This in turn will help in identifying research gaps, and thus offer directions for future research. By developing issue arena theory, a foundation can be laid for corporate communication strategy making that addresses the current complexity of the international environment by combining previous insights.

During recent decades, the field of communication for organizations has broadened rapidly. Attention has shifted from the micro level of communication activities to the meso level of communication within organizations and the macro level of the management of communication with stakeholders in the social environment (Stockholm Accords, 2010; Vos and Schoemaker, 2011). Currently, the emphasis is on the strategic interface function of communication for organizations (Sutcliff, 2001).

The discipline developed from aiming at goodwill and mutual relations to also acknowledging possibly conflicting interests in the field of forces in which organizations operate. Different public groups have different expectations that need to be monitored and cannot always be combined in win-win scenarios. Although most scholars agree that selfreferentiality in organizations (Van Woerkum, 1997) needs to be counteracted, many existing models continue to reinforce a self-centred picture of the organization, assuming that all the stakeholders have a shared stake in the organization, whereas in fact the parties involved may rather have an interest in specific issues and possibly opposite points of view. Stakeholders' expectations, formed in issue arenas, influence how the organization is perceived, and thus the interaction on an issue and its results will be reflected in the reputation of the organization.

Furthermore, organizations have to take many evolving issues into account in a situation that is more dynamic than ever (Stockholm Accords, 2010). It has been suggested that communication management calls for multiple situation-dependent strategies (Flynn, 2006). Thus, the challenges of operating in various and fast developing issue arenas need to be addressed. Developing an analytical model to investigate communication in issue arenas can help identify directions for research, describe and understand interaction processes and, ultimately, facilitate the development of communication strategy decisions in complex and turbulent environments.

\section{The concept of an issue arena}

In corporate communication, the concept of an issue arena has been suggested to lead to a more dynamic stakeholder model, and thus refers to the interaction of stakeholders regarding an issue in the public debate in the traditional or virtual media (Luoma-aho and Vos, 2010).

Aula and Mantere (2008) mentioned reputation arenas as places of interaction between an organization and its publics where the reputation of the organization is created. However, in an 
Marita Vos, Henny Schoemaker, and Vilma Luoma, Setting the agenda for research on issue arenas. Corporate Communications, an International Journal, Vol.18 No. 2, pp. 200-2015.

issue arena, the focal point is no longer the organization but the issue. A stakeholder is "one that holds a stake in the issue" (Van Schendelen, 2010). Heath $(1998,2002)$ introduced an issues management point of view into the field of public relations, advocating corporate public policymaking and balancing interests in society. Organizations aim at legitimacy for their activities, and therefore need to be willing to participate in such a debate and be held accountable for the decisions made. They may also seek change, for example in legislation, which they need to draw attention to, or they may need to find solutions for broader problems that could be addressed in the public debate. In issue arenas, alliances may be sought and negotiations initiated. As there are multiple interdependences in society, many different interests will also be reflected in the debate.

The term 'arena' can refer to a concrete place or an abstract concept. For an economist, a market arena may be a concrete place, such as a trade fair, but more often it is seen as an abstract concept referring to (all those places) where demand and supply meet for a product or service (Leeflang and Beukenkamp, 1987). Similarly, an issue arena can be a concrete place or medium for discussion on an issue, but first and foremost it is seen an abstract concept referring to (all those places) where exchange of views on this issue takes place. By using the term arena rather than sphere or place, the competitiveness of the interplay between the actors is acknowledged. An issue arena has been compared to a theatre (Luoma-aho and Vos, 2010), where the focus of the interaction is the stage (rather than the wings or rows of seats); similarly, in an issue arena, the focus is on what is visible in the public sphere rather than in the lobby outside public view.

According to Giddens (2009, 47), "Society needs an open public sphere in which debate about policy issues can be carried on”. The transformation of the public sphere has been discussed by Habermas (1991). Habermas (2006: 415) pictures the public sphere as "an intermediary system of communication between formally organized and informal face-to-face deliberations in arenas at both the top and the bottom of the political system" in which public opinions are jointly constructed by politicians and diffuse audiences from published and polled opinions. Habermas (1997: 360) describes the public sphere as "a network for communicating information and points of view" and states that the public sphere is reproduced through communicative action, emphasizing the role of the media. However, there are failures in the maintenance of a self-regulating media system and of proper feedback between the public sphere and civil society, as the assimilation of political issues by entertainment modes and polarization of conflicts promote a mood of antipolitics (Habermas, 2006). Habermas (1997) states that within the public sphere various arenas and platforms exist. Here we address issue arenas, arenas that focus on the public debate about a particular issue among various actors in both traditional and virtual media. It is suggested that, nowadays, next to news media also the social media have an important role in agenda setting of issues (Meriläinen and Vos, 2011).

The paper is organized as follows. First, the theoretical basis of issue arena thinking is established, and four theoretical approaches are highlighted: stakeholder thinking, network theory, issues management and agenda setting. Drawing on these, the authors propose a preliminary model with four levels of analysis: analysis relating to the issue itself, the actors involved, the media context and the course of the debate. For each level, examples are provided, and ideas for future studies proposed. Next, the limitations and implications of the proposed approach are presented. 
Marita Vos, Henny Schoemaker, and Vilma Luoma, Setting the agenda for research on issue arenas. Corporate Communications, an International Journal, Vol.18 No. 2, pp. 200-2015.

\section{Theoretical basis}

The term 'issue arena' is sparingly used and often not clarified further. For example, Ungericht and Hurt (2004) mention the decision of companies to engage in corporate social responsibility as a result of political processes in an issue arena. However, they do not define the concept. Similarly, Wassenberg (1991) mentions an 'arena approach' to negotiations without defining what this is.

In political science, the term 'arena' has a long history (e.g. Schattschneider, 1960). Arena analysis, in turn, is a current lobbying research approach which unites the earlier approaches of ruler, issue and stakeholder analysis (Van Schendelen, 2010). However, the political arena is seen as a composition of actors and issues, and the emphasis is on influencing the political agenda rather than on communication strategies in the public debate.

The concept of the issue arena offers a theoretical approach suitable for corporate communication in today's complex and turbulent social environment. The literature provides many starting points for such a theory (Luoma-aho and Vos, 2010). Here we focus on four of these, and show how they can be united to generate new knowledge on communication in issue arenas: (1) stakeholder thinking, (2) network theory, (3) issues management and (4) agendasetting theory. For each area, its origins and virtues will be briefly described, along with criticisms and recent insights related to communication in issue arenas. This will also show that in all four areas some cross-pollination already exists.

\section{Stakeholder thinking}

An often-cited milestone in the development of the stakeholder perspective is Freeman's (1984) book "Strategic Management: A Stakeholder Approach", which set in train the development of contemporary stakeholder research (e.g. Frooman, 1999; Näsi, 1995; Rowley, 1997). Scholars exploring stakeholder thinking have focused on stakeholder definitions and theory debates, stakeholder identification, stakeholder actions and responses, organizational actions and responses, and organizational performance (Rowley, 1997; Laplume et al., 2008). This has also contributed to understanding of the mutual dependence between an organization and its constituents (Rhenman 1964 in Näsi 1995), and the diversity of stakeholder interests and views (Donaldson and Preston, 1995; Rowley, 1997).

The stakeholder perspective has also been criticized for various shortcomings, in part due to the simplified graphical presentation of the model (Fassin, 2008): these concern, e.g., heterogeneity within stakeholder groups (Winn, 2001; Wolfe and Putler, 2002), the existence of one central organization (e.g. Friedman and Miles, 2002; Frooman, 1999; Rowley, 1997), multiple linkages (Key, 1999) and network relationships (Rowley, 1997; Roloff, 2008). In addition, the model can be criticized for not adequately accounting for various layers or spheres of the environment (Clarkson, 1995; Post, Preston and Sachs, 2002), dynamic aspects of the environment (Key, 1999), or the issue-specific and changing nature of stakeholder roles and relationships (Winn, 2001; Friedman and Miles, 2002).

Consequently, the focus of stakeholder research is shifting away from studying how stakeholders can be identified and classified from the perspective of a central organization (Koschmann, 2009) towards understanding and identifying stakes (Wu, 2007) and interrelations between stakes and their holders (Luoma-aho and Paloviita, 2010) within complex networks of 
Marita Vos, Henny Schoemaker, and Vilma Luoma, Setting the agenda for research on issue arenas. Corporate Communications, an International Journal, Vol.18 No. 2, pp. 200-2015.

multiple and sometimes conflicting interests and priorities (Roloff, 2008). Accordingly, an alternative definition of a stakeholder has been proposed: any group or individual who can affect or is affected by an issue addressed by the network that the group or individual is involved in (Roloff, 2008).

Topics related to stakeholder theory of particular interest for communication in issue arenas include shared interests, and how issues and stakes may be related.

\section{Network theory}

The mathematical foundations of the network concept can be traced back to the $19^{\text {th }}$ century, while interest in network approaches grew among scholars in social anthropology and social psychology in the first half of the $20^{\text {th }}$ century (Quandt, 2008). It is only in the past twenty years that there has been a clear growth of interest in this phenomenon, especially in Internet research, organizational science, policy studies and epidemiology (Wasserman, 2003), and in research on organizations and communication (Monge and Contractor, 2003). The basic purpose behind network analysis is to study relational systems in which actors, e.g. persons or organizations, are "embedded” (Granovetter, 1985) in order to examine how relationships and their structures influence behaviours (Rowley, 1997). Structure is treated as a network of networks that may or may not be portioned into discrete groups (Wellman, 1988). In this way, network theory addresses relationships between the actors within a network and interdependency of various networks, creating a basis to study the communication between an organization and its stakeholders, as well as communication in broader inter-organizational networks.

In its simplest terms, a network is “a set of interconnected nodes” (Castells, 2000: 152). Networks can be depicted with network graphs and described using formal mathematical language (Quandt, 2008). In research, while the focus may predominantly be on the structure of networks, connections have also been studied as a resource (Borgatti and Foster, 2003). Different roles in the network have been identified, for example, a bigger actor may function as a gatekeeping hub (Carpentier, 2011). The roles in the network affect the interplay between the actors, for example, the hub may prevent or allow further discussion of issues brought up by smaller actors, influencing the spreading of issues.

The network concept has been criticized for its ambiguity. It is applied to many different phenomena (Monge and Contractor, 2003), and is also used in a purely metaphorical sense, as “a web-like phenomenon” (Quandt, 2008). This has caused the concept to become rather vague.

In recent years, the relations making up a network have been emphasized. Patterns of relationships between members of a network also affect organizational behaviour, and rather than studying dyadic relations, an organization's environment is nowadays seen as a set of social actors (Rowley, 1997). Moreover, from the perspective of networks, connections are made with stakeholder theory and issues management. For example, Roloff (2008: 238) mentions multistakeholder networks "in which actors from civil society, business and governmental institutions come together in order to find a common approach to an issue that affects them all”.

Network theory-related topics of particular interest for communication in issue arenas include network roles, such as being a gatekeeper, connections between different networks, and the behaviour of hubs in issue debate. 
Marita Vos, Henny Schoemaker, and Vilma Luoma, Setting the agenda for research on issue arenas. Corporate Communications, an International Journal, Vol.18 No. 2, pp. 200-2015.

\section{Issues management}

The concept of issues management derives from the late 1970s and underlines the importance of public opinion for organizations (Heath and Cousino, 1990; Heath, 1986). Issues management is a function that helps organizations to understand and strategically adapt to their environment (Heath, 1998). Rather than creating an illusion of being able to fully 'manage' issues, issues management literature stresses ethics of organizational behaviour and sensitivity towards the social environment. Issues management is seen as stewardship for building, maintaining and repairing relationships with stakeholders and stakeseekers, contributes to strategic planning and enhances the organisation's ability to monitor issues, achieve standards of corporate responsibility, and engage in strategic public policy dialogue (Heath, 2002). It is only within the context of issues management that the gathering of information is translated into strategic organizational decision making (Lauzen, 1997). For example, in political sciences literature it is mentioned that strategies and tactics can be used to attempt to expand or shrink the scope of the issue (Schattschneider, 1960). In issues management the emphasis is on preventing organizational crises (Vos and Schoemaker, 2011). For this purpose, involvement in public policies is the objective of issue management and a proactive task for addressing issues (Coombs, 1992).

Downs (1972) proposed an issue attention cycle comprising various stages, in which the attention paid to an issue is low in the pre-problem stage, rises in the next stage, creating the willingness to take action, then shows a gradual decline, and ends in the post-problem stage. Hilgartner and Bosk (1988) criticized the issue attention cycle because it ignores the fact that issues as well as the ways in which they are framed compete for the public's attention. In this view, issues management is also related to framing. Therefore, issues management literature takes framing into account, connecting this also with rhetorical theory. A frame is an interpretation scheme that provides a context for understanding information and defining the situation (Hallahan, 1999). Framing stresses certain aspects of issues over others, and thus it is a selective process (Lecheler and De Vreese, 2010). The actors in the debate may frame the issue in different ways.

Game theory is also used to address how different interests are negotiated between the actors involved in an issue and to predict outcomes (Murphy, 1987; Bueno de Mesquita, 2009). As Weick (2001) puts it, people are enacting their environment. Perceptions of other actors and expected reactions influence behaviour in public debate on an issue. Recently, issues have been related to networks. Carpenter (2011) states that only the bigger and central actors in a network, called 'hubs', can influence issue salience in networks, while smaller actors need to collaborate with the more powerful hubs.

Topics in the area of issues management of particular interest for communication in issue arenas include negotiating interests, monitoring development of issues, framing and how this relates to strategic policy. 
Marita Vos, Henny Schoemaker, and Vilma Luoma, Setting the agenda for research on issue arenas. Corporate Communications, an International Journal, Vol.18 No. 2, pp. 200-2015.

\section{Agenda-setting theory}

The theory of agenda setting was initiated by McCombs and Shaw (1972) on the basis of earlier work (e.g. Lippmann, 1922), and postulates that a clear connection exists between news media coverage and public opinion. When reporting issues, the media underscore some of these (Sheafer, 2007), and as a result the issue gains salience in public perception. In priming, the media repeat and emphasize the importance of issues, and so cause particular issues to appear more relevant in the eyes of the public (Weaver, 2007). Weaver (1990) suggests that the media agenda is, in fact, formed together by politicians, their advisors and journalists. In this way, the agendas of the public, the media and the decision-makers are unified (Young and McCarthy, 2009).

Uscinski (2009) argues that the classical agenda-setting theory leads to overestimation of the power of the media to influence public opinion, and proposes the concept of an audience-driven framework, where the public influences the media. In an audience-driven agenda setting, issues discussed by the public lead the media to adjust their agenda. It remains unclear what communication processes actually lead to agenda setting and what role the various actors have. This has led some authors to favour the concept 'public debate', which refers to the public sphere (Habermas, 1991).

Nowadays it is stressed that the news media are not the only place for agenda setting. The prevalence of online communication channels creates more opportunities for organizations and publics to interact directly. Internet users can discuss issues and subsequently influence agenda setting (Roberts, Wanta and Dzwo, 2002). From the perspective of agenda setting, connections are also made with issue management and networks. For example, Carpenter (2011) mentions issue agendas and issue salience within an advocacy network, and Meriläinen and Vos (2011) connect agenda setting to the public debate on issues.

The four theoretical areas described above provide important insights into communication in issue arenas and show interconnections that invite their further development into an integral basis for understanding and investigating communication in issue arenas. Before suggesting research directions for this topic, different levels for the analysis of an issue arena will be clarified.

Within agenda-setting theory, topics of particular interest for communication in issue arenas include drawing attention to issues, and transfer between public, media and policy agendas.

\section{Towards different levels of analysis}

Organizations take part in various issue arenas and in each of these may encounter a very different environment when interacting with the relevant stakeholders. Issue arenas differ in many ways, according to the issue, the actors involved and the course of the debate. Based on the theories presented above, we suggest four levels of analysis that might contribute both to a better understanding of issue arenas and reveal their diversity. The debate will be influenced not only by the characteristics and context of the issue in question, but also by the actors and the roles they take. The discourse and the spread of the issue debate will also be related to the places of interaction, and the features of the media involved. In addition, the course of the debate over time needs to be taken into account. A preliminary analytical model of the four levels of analysis of communication in issue arenas is presented below in figure 1 . 
Marita Vos, Henny Schoemaker, and Vilma Luoma, Setting the agenda for research on issue arenas. Corporate Communications, an International Journal, Vol.18 No. 2, pp. 200-2015.

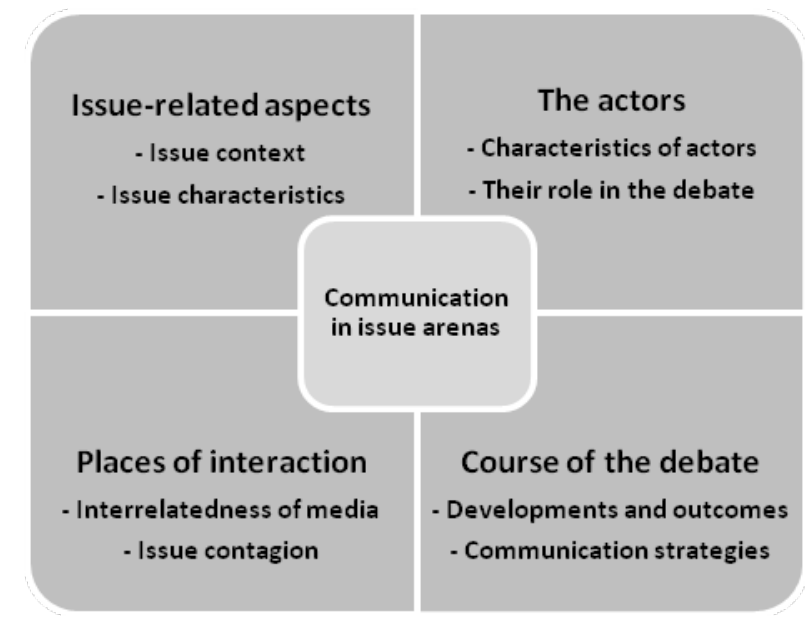

Figure 1. Analytical model of communication in issue arenas.

\section{Level 1: Issue-related aspects}

Issue arenas are likely to differ according to the characteristics of the issues in question. Each issue exists in a particular situational context and thus is more or less associated with political or economic interests, which can be considered to set the stage for arena interaction and open up options for framing the issue (Meriläinen and Vos, 2013). The context also explains how a particular issue relates to the actors' organizational policies. Perceptions of an issue can be explained by its historical background and associations.

Issues differ in scope, with case-specific issues relating to a broader cluster of issues: for example, whereas food safety has long been a hot topic, there may be sub-arenas debating additives in particular products. Issue salience is influenced by the use of framing (Hallahan, 1999), and different ways to frame social issues have been investigated, for example, in issues of human rights (Meriläinen and Vos, 2013).

To better understand how issues and stakes are related, insights from stakeholder theory could be utilized, while for issue framing, and how this relates to organizational policies, insights from issues management could prove useful.

\section{Level 2: The actors involved}

In some issue arenas, many stakeholders are actively involved, as in the issue of global warming. In other arenas, only a few of the potential actors are active, such as in the Brent Spar case, where, during the occupation of the platform by the activists, Greenpeace primarily confronted Shell, leaving Esso, the co-owner of the platform, out of the public discussion. Actors have different characteristics, of which credibility (Druckman, 2001), legitimacy (Coombs, 1992) and power (Lukes, 1974), in particular, have been suggested to be important in public debate.

Actors can become active in an issue arena because they see opportunities, or because they are drawn into it by the course of events. Actor roles also differ, for example the United Nations, which can act as initiator or mediator.

The roles of the actors in an issue arena also have to do with the actors' inter-relatedness. The concept 'network' seems to suggest contact; however, there may not be direct contact, with 
Marita Vos, Henny Schoemaker, and Vilma Luoma, Setting the agenda for research on issue arenas. Corporate Communications, an International Journal, Vol.18 No. 2, pp. 200-2015.

points of view being encountered only in the media, while some actors may only want to address the audience. In a network of strong and weak ties, contact may be direct, indirect or even absent (Granovetter, 1973).

To better understand the different roles of actors in issue arenas, insights from network theory can be used, while stakeholder theory can shed light on the inter-relatedness of actors operating in an issue arena.

\section{Level 3: Places of interaction}

An issue can be discussed in both physical and virtual space. For example, in the international climate change conference in Copenhagen in 2009, virtual spaces for the exchange of opinions were also made available. Today, public debate takes place not only in settings where people can meet and exchange views in direct contact or supported by technology such as teleconferences, but also in traditional media, such as newspapers, radio and television, and in virtual media in the online environment, such as discussion platforms, social networks and Twitter.

Each place of interaction has particular features that need to be taken into account by the participants in the debate. Journalists draw most material from well-organized information producers, though civil society actors can also join together to promote issues in the public sphere (Habermas, 1996). Consequently, news media pay most attention to prominent actors, while social media provide expression possibilities for many. It has been suggested that interaction has been accelerated by the Internet (Self, 2010) and that social media interaction causes issue contagion (Coombs, 2002). Furthermore, social media debate may lead to an issue gaining attention in the traditional media and vice versa (Meriläinen and Vos, 2011).

To understand how attention is drawn to issues and how issue debate spreads from the social to the news media, agenda-setting theory can offer useful insights.

\section{Level 4: Course of the debate}

Issue arenas may develop and differ according to the issue development phase (Downs, 1972). The emphasis in the debate may also change. For example, Al Gore drew attention to the issue of global warming, but also guided the debate on global warming so that the focus remained exclusively on carbon dioxide, leaving other harmful substances out of the debate.

Various factors influence the course and outcomes of a debate. In some cases solutions sought by many may be blocked by one actor, making it difficult to solve, for example, immigration issues. Furthermore, an organization may use different communication strategies suited to each new issue arena in which it is active. However, to maintain a clear identity, companies need to develop an appropriate balance zone for their organization (Flynn, 2006). This calls for the building of a strategy portfolio by companies in issue arenas.

To follow the course of a debate, insights from issue management and, in particular, the issue life cycle may be of value. 
Marita Vos, Henny Schoemaker, and Vilma Luoma, Setting the agenda for research on issue arenas. Corporate Communications, an International Journal, Vol.18 No. 2, pp. 200-2015.

\section{Research directions}

Research could further investigate communication in issue arenas by focusing on the levels of analysis that we have described. Below we present examples within one such level of analysis, highlight one promising element, and describe an integral approach using all four levels of analysis.

\section{Research within the various levels of analysis}

Future studies may focus on:

- Issue-related aspects, e.g. the way in which issues are framed in a debate, and clarify the interrelatedness of different issue arenas and how this affects the interplay between the actors.

- Actors involved, e.g. developing a typology of stakeholders focused on arena behaviour. The interrelatedness of actors could be investigated. Attention could also be given to cases in which problem solving is blocked by one actor.

- Places of interaction, e.g. the media aspects of issue arenas and how issue discussion in traditional media is related to social media discourse, and the speed and pattern pertaining to the spread of issues in the social media.

- Course of the debate, e.g. critical factors influencing the course and predicting the outcome of a debate, and using game theory (e.g. Bueno de Mesquita, 2009) to focus on communication strategies in the public debate.

\section{Investigating the course of the public debate in issue arenas}

In the current communication literature, the last level of analysis, in particular, has not yet been much investigated. Drawing on the actor-network theory (Latour, 2005), we propose to analyse balance in issue arenas. An issue arena is constantly in flux and can be more or less active. Homeostasis (a relatively stable situation) occurs when the current situation is accepted by most actors. In such cases, the issue arena is expected to be relatively quiet. However, the gap between the current and desired situation regarding the issue will be different for all actors, causing more or less tension. Because of power differences, the current situation or solution to an issue may benefit some actors more than others. However, when homeostatic imbalance is too high, for example when a few actors have forced a particular outcome, harming other interests, increased activity in the issue arena is likely. This could be further investigated.

There may be a point where mutual acceptance peaks, although actors have different points of view and resources that also vary over time and according to the situation. Organizations can aim at maximising their benefits or at a situation closer to homeostasis to obtain a more sustainable outcome of the debate. Such a research focus could clarify organizational policymaking in issue arenas. 
Marita Vos, Henny Schoemaker, and Vilma Luoma, Setting the agenda for research on issue arenas. Corporate Communications, an International Journal, Vol.18 No. 2, pp. 200-2015.

\section{An integral approach using all four levels of analysis}

First and foremost, we recommend a more thorough and integral approach to the investigation of communication in issue arenas, one that takes all four levels of analysis into account. To ensure that the content of the issues studied and their context are taken into account, studies could focus on a topic field or on particular cases within such a field. Examples are given in table 1.

\begin{tabular}{|l|l|l|}
\hline Topic field & Energy sources & Food safety \\
\hline $\begin{array}{l}\text { Issues of current } \\
\text { public debate } \\
\text { (examples) }\end{array}$ & $\begin{array}{l}\text { Energy dependency and sufficiency; } \\
\text { sustainability; nuclear energy; } \\
\text { renewable energy; smart grid }\end{array}$ & $\begin{array}{l}\text { Risks such as BSE and bird flu; } \\
\text { food additives and intolerances; } \\
\text { bio-industry; genetic modification }\end{array}$ \\
\hline $\begin{array}{l}\text { Issue-related } \\
\text { aspects }\end{array}$ & $\begin{array}{l}\text { Framing of technology and security } \\
\text { aspects; associations with global } \\
\text { warming }\end{array}$ & $\begin{array}{l}\text { Framing of health and technology-related } \\
\text { risks; associations with animal welfare }\end{array}$ \\
\hline $\begin{array}{l}\text { Actors involved } \\
\text { Roles in the debate of, e.g. energy } \\
\text { users, authorities and states on } \\
\text { various levels; environmental NGOs; } \\
\text { international context }\end{array}$ & $\begin{array}{l}\text { Roles in the debate of, e.g. food and farming } \\
\text { industry, distributors; consumers; authorities } \\
\text { and states on various levels; animal rights } \\
\text { NGOs and consumer unions; international } \\
\text { context }\end{array}$ \\
\hline $\begin{array}{l}\text { Places of } \\
\text { interaction }\end{array}$ & $\begin{array}{l}\text { monitoring news media and social media discourse, with an eye to the inter- } \\
\text { relatedness of discussions in different spaces of interaction }\end{array}$ \\
\hline $\begin{array}{l}\text { Course of the } \\
\text { debate }\end{array}$ & $\begin{array}{l}\text { The discussion and outcomes over time, identifying the factors influencing the course } \\
\text { of events or testing predicted outcomes }\end{array}$ \\
\hline
\end{tabular}

Table 1. Examples of topic fields and specific issues for further investigation.

Within the topic of energy sources, many issues are under debate and framed in various ways, such as energy dependency and sufficiency, sustainability, nuclear energy, renewable energy and the smart grid. This involves issue arenas in traditional and virtual media, and actors such as energy producers and distributors, users, authorities and states on various levels, and environmental NGOs. The actors have different roles in the debate and the discussion is shaped by the international context and the related competitive situation.

Similarly, the topic of food safety is discussed in issue arenas on, for example, BSE and bird flu, food additives and intolerances, bio-industry, and genetic modification. Many of these issues are health risk-related and have international relevance. The risks are framed in different ways by the various actors that include the food and farming industry, distributors, consumers, authorities and states on various levels, but also animal rights NGOs and consumer unions, for example.

An integral approach to analysing issue arenas involves viewing the topic discussed through the lenses of the organizations and other actors involved, while also taking into account the current context to better understand the interplay present in often complex situations. 
Marita Vos, Henny Schoemaker, and Vilma Luoma, Setting the agenda for research on issue arenas. Corporate Communications, an International Journal, Vol.18 No. 2, pp. 200-2015.

\section{Conclusions}

In this paper, we proposed a theoretical foundation that draws mostly on four distinct theoretical areas: stakeholder thinking, network theory, issues management and agenda setting. Through these, we identified different levels of analysis to further investigate communication in issue arenas: the issue itself, the actors involved, media aspects and the course of the debate. Examples of each level were provided, and a preliminary model for analysis proposed.

To conclude, we see the concept of the issue arena as referring to the interaction among stakeholders on an issue in the public debate in the traditional or virtual media. Thus, issues are not seen as the social context in which an organization functions, but instead issues and the values behind them are central in discussions with stakeholders. This approach doesn't depict the organization as the central node connecting stakeholders, with issues as the context, but emphasizes the interplay among organizations and other actors.

Organizations no longer control communication; instead, in the public debate on issues, groups and individuals compete equally for attention. Issue arenas can be more or less stable, depending on the perceived deviation between the current and the desired situation regarding the issue. Various communication strategies can be utilized, from one-way advocacy to two-way collaboration, aiming at decision-making or non-decision making regarding the issue.

\section{Implications for practice}

Though this paper primarily focuses on setting the research agenda, the complexity and dynamic nature of issue arenas, also addressed here, have implications for corporate communication strategies. In issue arenas, actors compete for attention (Luoma-aho and Nordfors, 2009). Communication strategies include information, persuasion, consensus-building and dialogue (Van Ruler, 2004), one-way advocacy and two-way collaboration, and symmetry versus asymmetry (Grunig, 1992). A combination of strategies is generally chosen, including framing strategies to increase issue salience (Hallahan, 1999). As different communication strategies may be chosen to fit the particularities of each issue arena, organizations may develop an integral approach, uniting these strategies within a balance zone in order to maintain a clear identity (Flynn, 2006).

In issue arenas, we assume that the actors will use strategies of all kinds, depending on the situation, and in addition use various platforms, including social media, to engage in issue discussion. For example, actors may facilitate dialogue and empowerment for problem solving and sustainable solutions. Moreover, they may aim at decision-making or non-decision-making by keeping issues out of the discussion (Bachrach and Baratz, 1962). Organizations may address core issue arenas, identifying places where these issues are discussed or discussion may be initiated, monitor changing expectations relevant for their reputation, and develop a balanced portfolio of corporate communication strategies.

\section{Implications for research}

As a theoretical contribution, this paper has many limitations. First, it presents an ideal framework for issue arenas that in practice may prove difficult to adhere to. Second, it does not acknowledge that organizations are at different stages in the development of their participation strategies, and that some are keener than others to engage in discussions in issue arenas. 
Marita Vos, Henny Schoemaker, and Vilma Luoma, Setting the agenda for research on issue arenas. Corporate Communications, an International Journal, Vol.18 No. 2, pp. 200-2015.

Moreover, in many sectors the new and social media continue to play a minor role, and traditional stakeholder approaches can still be applied.

Despite these limitations, we believe that further development of issue arena theory can provide important insights for communication in complex and dynamic environments. We provided a theoretical basis using related insights from stakeholder thinking, network theory, issues management and agenda-setting theory. The four levels of analysis set forth could serve as a starting point for future studies with a focus on characteristics of the issue and context, the actors involved and their roles and the media context, as well as the course of the debate and the communication strategies utilized. In analyzing complex issues through the lens offered by this model, the central focus is on the interplay of actors with the aim of clarifying communication strategies in dynamic and interrelated issue arenas.

We conclude that in corporate communication practice nowadays specialist knowledge of communication strategies also includes identifying relevant issue arenas and understanding that the interplay of actors has accelerated in the internet environment. Communication strategies need to suit each issue arena, while a balance zone is suggested to maintain a clear corporate identity. Developing an issue arenas approach will contribute to understanding of the complexity of the current corporate communication environment.

\section{Acknowledgements}

The authors thank Niina Meriläinen and Aino Ruggiero for contributing to the literature search on the theoretical areas that can help explain communication in issue arenas.

\section{References}

Aula, P. \& Mantere, S. (2008). Strategic reputation management. Towards a company of good. London: Routledge.

Bachrach, P. and Baratz, M.S. (1962), “Two Faces of Power”, The American Political Science Review, Vol. 56 No.4, pp. 947-952.

Borgatti, S.P. and Foster, P.C. (2003), "The network paradigm in organizational research: A review and typology”, Journal of Management, Vol. 29 No 6, pp. 991-1013.

Bueno de Mesquita, B. (2009), Predictioneer; one who uses math, science, and the logic of brazen self-interest to see and shape the future, London: The Bodley Head.

Carpenter, C. (2011), "Vetting the advocacy agenda: network centrality and the paradox of weapons norms”. International Organization 65, Winter 2011, pp. 69-102.

Castells, M. (2009), Communication power, Oxford University Press: Oxford.

Castells, M. (2000), "The contours of the network society”, The Journal of Future Studies, Strategic Thinking and Policy, Vol. 2 No. 2, pp. 151-157.

Clarkson, M. B. E. (1995), “A stakeholder framework of analyzing and evaluating corporate social performance”, Academy of Management Review, Vol. 20 No. 1, pp. 92-117. 
Marita Vos, Henny Schoemaker, and Vilma Luoma, Setting the agenda for research on issue arenas. Corporate Communications, an International Journal, Vol.18 No. 2, pp. 200-2015.

Coombs, W.T. (1992), "The failure of the task force on food assistance: a case study on the role of legitimacy in issue management”, Journal of Public Relations Research, Vol. 4 No. 2, pp. 101-122.

Coombs, T. (2002), “Assessing online issue threats: issue contagions and their effect on issue prioritization. Journal of Public Affairs”, Vol. 2, No. 4, pp. 215-229.

Donaldson, T. and Preston, L. (1995), “The stakeholder theory of the corporation: concepts, evidence, and implications”, The Academy of Management Review, Vol. 20 No. 1, pp. 6591.

Downs, A. (1972), “Up and down with ecology - the 'issue-attention cycle' ”, Public Interest, Vol. 28, pp. 38-50.

Druckman, J. N. (2001), ”On the limits of framing effects: who can frame?” The Journal of Politics, Vol. 63 No. 4, pp. 1041-1066.

Fassin, Y. (2008), “Imperfections and shortcomings of the stakeholder model’s graphical representation”, Journal of Business Ethics, Vol. 80, pp. 879-888.

Flynn, T. (2006), “A delicate equilibrium: balancing theory, practice and outcomes”, Journal of Public Relations Research, Vol. 18, pp. 191-201.

Freeman, E. (1984), Strategic management: a stakeholder approach, Boston: Pitman (reprinted 2010 by New York: Cambridge University Press).

Friedman, A. L. and Miles, S. (2002), "Developing stakeholder theory”, Journal of Management Studies Vol. 39 No. 1, pp. 1-21.

Frooman, J. (1999), “Stakeholder influence strategies”, Academy of Management Journal, Vol. 24 No 2, pp. 191-205.

Giddens, A. (2009), The third way: The renewal of social democracy. Cambridge: Polity Press. Granovetter, M. (1973), “The strength of weak ties”, American Journal of Sociology, Vol. 78 No. 6, pp. 1360-1380.

Granovetter, M. (1985). "Economic action and social structure: The problem of embeddedness". American Journal of Sociology, Vol. 91 No. 3, pp. 481-510.

Hallahan, K. (1999), "Seven models of framing; Implications for public relations”. Journal of Public Relations Research, Vol. 11 No. 3, pp. 205-242.

Habermas, J. (1991), The structural transformation of the public sphere; An inquiry into a category of bourgeois society, Massachusetts Institute of Technology, Cambridge.

Habermas, J. (1996), Between facts and norms: Contributions to a discourse theory of law and democracy. MIT Press Cambridge MA.

Habermas, J. (2006), Political communication in media society: Does democracy still enjoy an epistemic dimension? The impact of normative theory on empirical research. Communication Theory, 16, 411-426.

Heath, R. (1986), Issues management: Corporate public policymaking in an information society, Sage, London.

Heath, R.L. (2002), Issues management: Its past, present and future. Journal of Public Affairs, 2(4), 209-214.

Heath, R.L. and Cousino K.R. (1990), Issues management: End of first decade progress report, Public Relations Review, XVI (1), 6-18. 
Marita Vos, Henny Schoemaker, and Vilma Luoma, Setting the agenda for research on issue arenas. Corporate Communications, an International Journal, Vol.18 No. 2, pp. 200-2015.

Heath. R.(1998), "New communication technologies: An issue management point of view", Public Relations Review, Vol. 24 No.3, pp. 273-288.

Hilgartner, S. and Bosk, C.L. (1988), "The rise and fall of social problems: A public arenas model”, American Journal of Sociology, Vol. 94, pp. 53-78.

Key, S. (1999), “Toward a new theory of the firm: A critique of stakeholder 'theory' ”, Management Decision, Vol. 37 No. 4, pp. 317-328.

Koschmann, M. (2009), The communicative constitution of stakeholder identification. Paper presented at the Annual Meeting of the International Communication Association, pp. 131.

Laplume, A., Sonpar, K. and Litz, R. (2008), “Stakeholder theory: Reviewing a theory that moves us”, Journal of Management, Vol. 34 No. 6, pp. 1153-1189.

Latour, B. (2005), Reassembling the social: An introduction to actor-network-theory. Oxford University Press, Oxford.

Lauzen, M. (1997), Understanding the relation between public relations and issues management, Journal of Public Relations Research, Vol. 9, No. 1, pp. 65-82.

Lecheler, S, and De Vreese, C.H. (2010), "Framing Serbia: The effects of news framing on public support for EU enlargement”, European Political Science Review, Vol. 2 No. 1, pp. 73-93.

Leeflang, P.S.H. and Beukenkamp, E.A. (1987), Probleemgebied marketing, een management benadering, Stenfert Kroese, Leiden.

Lippmann, W. (1922), Public opinion, Macmillan, New York.

Lukes, S. (1974), Power: A radical view, Macmillan, London.

Luoma-aho, V. and Nordfors, D. (2009), “Attention and Reputation in the Innovation Economy”, Innovation Journalism, Vol. 6 No. 2.

Luoma-aho, V. and Paloviita, A. (2010). ”Actor-networking stakeholder theory for today's corporate communications”, Corporate Communications: An International Journal, Vol. 15 No. 1, pp. 49-67.

Luoma-aho, V. and Vos, M. (2009), "Monitoring the complexities: nuclear power and public opinion”, Public Relations Review, Vol. 35 No. 2, pp. 120-122.

Luoma-aho, V. and Vos, M. (2010), "Towards a more dynamic stakeholder model: the role of issue arenas for corporate reputation”, Corporate Communication, an International Journal, Vol. 15 No. 3, pp. 315-331.

McCombs M. and Shaw, D. (1972), “The agenda-setting function of mass media”, Public Opinion Quarterly, Vol. 36 No. 2, pp. 176-187.

Meriläinen, N. and Vos, M. (2011), "Human rights organizations and online agenda setting”, Corporate Communication, an International Journal, Vol. 16 No. 4, pp. 293-310.

Meriläinen, N. and Vos, M. (2013), "Human rights organizations and online agenda setting”, Corporate Communication, an International Journal. Vol. 18 No. 1, pp. 119-134.

Monge, P. R. and Contractor, N. S. (2003), Theories of communication networks, Oxford University Press, New York.

Murphy, P. (1987), "Using games as a model for crisis communications”, Public Relations Review, Vol. 13 No. 4, pp. 19-28. 
Marita Vos, Henny Schoemaker, and Vilma Luoma, Setting the agenda for research on issue arenas. Corporate Communications, an International Journal, Vol.18 No. 2, pp. 200-2015.

Näsi, J. (1995), “What is stakeholder thinking? A snapshot of a social theory of the firm”, in Näsi, J. (ed.) Understanding stakeholder thinking, Helsinki: LSR-Publications, pp. 19-32.

Post, J. E., Preston, L.E. and Sachs, S. (2002), "Managing the extended enterprise: the new stakeholder view”, California Management Review, Vol. 45 No. 1, pp. 6-28.

Quandt, T. (2008), "Network analysis", in Donsbach, W. (ed.), The International Encyclopedia of Communication, Blackwell Publishing, available at:

http://www.communicationencyclopedia.com/subscriber/tocnode?id=g9781405131995_ch unk_g978140513199519_ss8-1 (assessed 23 February 2011).

Roberts, M., Wanta, W. and Dzwo, T.H. (2002), “Agenda setting and issue salience online”, Communication Research, Vol. 29 No. 4, pp. 452-465.

Roloff, J. (2008), “Learning from multi-stakeholder networks: issue-focussed stakeholder management”, Journal of Business Ethics, Vol. 82, pp. 233-250.

Rowley, T. J. (1997), "Moving beyond dyadic ties: a network theory of stakeholder influences, Academy of Management Review, Vol. 22 No.4, pp. 887-910.

Schattschneider, E.E. (1960), The Semisovereign people: A realist's view of democracy in America, Holt, Rinehart and Winston, New York, NY.

Self, C.C. (2010), "Hegel, Habermas, and community: The public in the new media era", International Journal of strategic communication, Vol. 4, pp. 78-92.

Sheafer, T. (2007), "How to evaluate it: the role of story-evaluative tone in agenda setting and priming”, Journal of Communication, Vol. 57 No. 1, pp. 21-39.

Stockholm Accords (2010), A call to action for public relations and communication in a global society, The World Public Relations Forum, Stockholm, Sweden, June 15, 2010. Available at: http://www.cipr.co.uk/sites/default/files/Stockholm-Accords-final-version.pdf (assessed 3 August 2012).

Sutcliffe, K. (2001), “Organizational environments and organizational information processing”, in Jablin, F. and Putnam, L., The new handbook of organizational communication; advances in theory, research and methods, London, Sage, pp.197 -230.

Ungericht, B. and Hirt, C. (2010), "CSR as a political arena: the struggle for a European framework”, Business and Politics, Vol. 12 No. 4, Article 1, 28 February 2011, available at:

http://www.degruyter.com/view/j/bap.2010.12.4/bap.2010.12.4.1303/bap.2010.12.4.1303.x ml?format=INT (accessed 3 August 2012)

Uscinski, J. (2009), "When does the public's issue agenda affect the media's issue agenda (and vice-versa)? Developing a Framework for Media-Public Influence”, Social Science Quarterly, Vol. 90 No. 4, pp. 796-815.

Van Ruler, B. (2004), “The communication grid: An introduction of a model of four communication strategies”, Public Relations Review, Vol. 30, pp. 123-143.

Van Schendelen, R. (2010), More Machiavelli in Brussels: The art of lobbying the EU, Amsterdam University Press, Amsterdam.

Van Woerkum, C.M.J. (1997), Communicatie en interactieve beleidsvorming, Bohn Stafleu Van Lochum, Houten.

Vos, M. and Schoemaker, H. (2011), Integrated communication; concern, internal and marketing communication, Eleven, The Hague. 
Marita Vos, Henny Schoemaker, and Vilma Luoma, Setting the agenda for research on issue arenas. Corporate Communications, an International Journal, Vol.18 No. 2, pp. 200-2015.

Wassenberg, A.F.P. (1991), “Onderhandelen: arena, agenda en timing; een politie- en ecponomisch-sociologisch perspectief”, in Kaplan, M.J.G.P. (red.), Onderhandelen; structuren en toepassingen, Schoonhoven: Academic Service.

Wasserman, S. (2003), Foreword: Multitheoretical, multilevel - and multianalytical, in Monge, P.R. and Contractor, N.S., Theories of communication networks, University Press, New York, Oxford, pp. vii-x.

Weaver, D. (1990), “Setting political priorities: what role for the press”, Political Communication, Vol. 7 No. 4, pp. 201-211.

Weaver, D. (2007), “Thoughts on agenda setting, framing, and priming”, Journal of Communication, Vol. 57 No. 1, pp. 142-147.

Weick, K. (2001), Making sense of the organization, Blackwell, Malden.

Wellman, B. (1988), "Structural analysis: from method and metaphor to theory and substance", in B. Wellman and S. D. Berkowitz (eds.), Social structure: A network approach, New York, Cambridge.

Winn, M. I. (2001), "Building stakeholder theory with a decision modeling methodology", Business and Society, Vol. 40 No. 2, pp. 133-166.

Wolfe, R. and Putler, D. (2002), "How tight are the ties that bind stakeholder groups?” Organization Science, Vol. 13 No. 1, pp.64-80.

Wu, X. (2007), "Stakeholder identifying and positioning (SIP) models: From Google's operation in China to a general case-analysis framework”, Public Relations Review, Vol. 33, pp. 415-425.

Young, R. and McCarthy K. (2009), "Why do municipal issues rise on the federal policy agenda in Canada?” Canadian Public Administration, Vol. 52 No. 3, pp. 347-370.

\begin{abstract}
About the authors
Marita Vos PhD is professor Organizational Communication and PR at the University of Jyväskylä, Finland.

Henny Schoemaker MSc is communication consultant and book author, Jyväskylä, Finland. Vilma Luoma-aho PhD is professor Organizational Communication and PR at the University of Jyväskylä, Finland.
\end{abstract}

\title{
Corresponding author
}

The authors can be contacted at: marita.vos@jyu.fi 